мегаконцепт и разворачивается в тексте песенного произведения в трех темпоральных измерениях: ПРОШЛОЕ, НАСТОЯЩЕЕ, БУДУЩЕЕ, которые выступают мезоконцептами произведения. Временные пространства ПРОШЛОЕ и БУДУЩЕЕ представлены эксплицитно, измерение НАСТОЯЩЕЕ выражено имплицитно по принципу зеркального отражения прошлого. В структуре мезоконцепта ПРОШЛОЕ выделяются мегаконцепты ЖИЗНЬ и РАЙ с соответствующими катаконцептамЫ: ГАРМОНИЯ и ПРИРОДА. Концепт НАСТОЯЩЕЕ представлен в мегаконцепте УНИЧТОЖЕНИЕ и катаконцептамЫ НАСИЛИЯ и ПОРАБОЩЕНИЯ. Концептуальными составляющими мезоконецпту НАСТОЯЩЕЕ выступают эмотивные концепты ПЕССИМИЗМ и НЕУВЕРЕННОСТЬ, а мезоконцепт БУДУЩЕЕ реализуется в художественном пространстве произведения в мегаконцепте СМЕРТЬ и соответствующих катаконцептах ФИЗИЧЕСКИЕ НЕДОСТАТКИ и ГОЛОД. Семантикокогнитивный аспект исследования также позволил проследить лингвальное выражение ключевых концептов авторской картины мира, установить концептуальные равенства début = paradis и rien = bien, а также выделить ключевую метафору произведения ЖИЗНЬ КАК ГНОЙНАЯ ЯМА.

Ключевые слова: концепт, текстовый концепт, художественное пространство, индивидуально-авторская картина мира, франкоязычный песенный дискурс.

Andriievska Viktoriia. Conceptual Analysis of the Individual Author's Picture of the World in the French Song Discourse. The article is devoted to the study of the individual author's picture of the world of the modern French song discourse, its conceptual analysis through the prism of textual concepts that encode the artistic author's idea of the work. The method of conceptual analysis of a artistic work and the method of studying textual concepts, their hierarchical structure, as well as methods of dictionary definitions, stylistic, lexical and grammatical, contextual and situational and interpretive analysis were used. The key textual concept of the artistic space in the composition «Respire» has been determined; traced its deployment in three temporal dimensions, presented in the conceptual space of the French song discourse, analyzed the lexical, semantic and stylistic means of verbalizing the textual concepts of the work, established the metaphorical and pragmatic properties of the textual concepts of the selected composition. Semantic and cognitive analysis of the illustrative material provided an opportunity to highlight the key textual concept of the artistic space LOST PARADISE, which in the conceptual hierarchy of textual concepts is defined as a mega-concept and unfolds in the text of a song work in three temporal dimensions: PAST, PRESENT, FUTURE, which are meso-concepts. Temporary spaces PAST and FUTURE are presented explicitly, dimension PRESENT is expressed implicitly according to the principle of mirror reflection of the past. In the structure of the meso-concept of the PAST, the mega-concepts of LIFE and PARADISE are distinguished with the corresponding cata-concepts: HARMONY and NATURE. The concept of PRESENT is presented in the mega-concept DESTRUCTION and the cataconcept of VIOLENCE and SUBMISSION. The conceptual components of the meso-concept of the PRESENT are the emotive concepts of PESSIMISM and UNCERTAINTY, and the meso-concept FUTURE is implemented in the artistic space of the work in the mega-concept DEATH and the corresponding cata-concepts PHYSICAL FAULTS and HUNGER. The semantic and cognitive aspect of the study also made it possible to trace the lingual expression of the key concepts of the author's picture of the world, to establish conceptual equalities beginning is paradise and nothing is good, and also to highlight the key metaphor of the work LIFE AS A PUSH PIT.

Key words: concept, textual concept, artistic space, individual author's picture of the world, French song discourse.

DOI: https://doi.org/10.32782/2410-0927-2020-13-2

УДК 378:371.311:811.11

Юлія Баклаженко

\title{
ЛІНГВІСТИЧНІ ПЕРЕДУМОВИ НАВЧАННЯ АНГЛІЙСЬКОГО ПРОФЕСІЙНО ОРІЕНТОВАНОГО ПИСЕМНОГО МОВЛЕННЯ В ЗАКЛАДАХ ВИЩОЇ ОСВІТИ
}

Навчання професійно орієнтованого писемного мовлення як засобу віддаленої комунікації та професіоналізації відіграє сьогодні значну роль у зв'язку з високими вимогами до підготовки фахівців ыз різних галузей знань. У статты розглянуто лінгвістичні передумови навчання англійського професійно орієнтованого писемного мовлення у закладах вищої освіти. Зокрема, окреслено характерні відмінності професійно орієнтованого технічного, академічного та творчого письма як комунікативних актів; визначено екстралінгвістичні й власне мовні риси професійно орієнтованого писемного мовлення, такі як точність викладу, лаконічність, доступне оформлення документа; орієнтованість на аудиторію, граматична, лексична та змістова правильність тексту. Виявлено, що для навчання професійно орієнтованого писемного мовлення важливе врахування таких характерних рис, як використання термінології, точність значення, усталений порядок слів у фразах, використання сталих висловів, застосування слів із вираженим технічним забарвленням, використання складних і складених лексем, утворених за різними моделями, застосування абревіатур, скорочень, пасивних конструкцій, інфінітива, герундія та герундіальних конструкцій, дієприкметника та дієприкметникових конструкцій. Зазначено також труднощі лінгвістичного характеру, із якими стикаються студенти під час написання текстів на професійно-технічну тематику.

(C) Баклаженко Ю., 2020 
Проаналізовано загальностилістичнні риси жанру ділового листа, його комунікативну функцію, структурнокомпозиційну будову, лінгвістичні особливості й відмінності з погляду навчання англійського професійно орієнтованого писемного мовлення в закладах вищої освіти.

Ключові слова: навчання англійської мови, англійське професійно орієнтоване писемне мовлення, англійська для професійних цілей, діловий лист

Вступ. Система вищої освіти України переживає нині значні зміни, що пов'язані з іiі входженням у європейський простір та впровадженням основних ідей і цілей Болонського процесу, зокрема забезпечення якісної вищої освіти для всіх, покращення здатності випускників до працевлаштування, посилення мобільності студентів і сприяння «студентоцентрованому» навчанню у вищій освіті [12, с. 1-2]. Відтак посилюються вимоги до підготовки фахівців із різних галузей знань, а навчання іноземних мов стає не лише метою, але й засобом забезпечення якості навчання, мобільності студентів і конкурентоспроможності випускників на світовому ринку праці. В умовах світової пандемії та скорочення фізичних контактів на перший план виходить навчання професійно орієнтованого писемного мовлення як потужного засобу віддаленої комунікації й професіоналізації.

Навчання професійно оріснтованого писемного мовлення студентів технічних спеціальностей набуло широкої популярності в західних методиках викладання під назвою “teaching technical writing” $[5 ; 9 ; 13 ; 14 ; 17]$, при цьому поняття «technical writing» досить широко трактують як писемний засіб комунікації у сфері бізнесу й промисловості, що фокусується на продуктах або послугах, має на меті тлумачення або роз'яснення питань, пов'язаних із розробкою, продажем, управлінням, доставкою та використанням об'єктів професійної діяльності й призначений для використання колегами, клієнтами, підлеглими та керівниками [9]. До професійно орієнтованого писемного мовлення західні дослідники відносять досить широке коло жанрів, зокрема такі, як меморандум, резюме, звіт, бізнес лист, презентація, електронний лист, патент, інструкція, керівництво з використання, наповнення вебсторінки та ін. Грунтовні дослідження такого жанру професійно орієнтованого писемного мовлення, як діловий лист, проведено як у лінгвістичній, так і в методичній площині. Так, проаналізовано лінгвістичні особливості ділового писемного мовлення (О. П. Биконя [4]), порівняно лексико-граматичні особливості українського та англійського ділових листів (Т. А. Крисанова [11]), проаналізовано дистанційне навчання ділового листування (Т. М. Базванова [2]), навчання ділового писемного спілкування 3 використанням електронного підручника (Т. М. Каменєва [10]) тощо. Д. Х. Даутова в результаті когнітивного типологічного аналізу ділових листів виявила такі їхні типи, як лист-запрошення, повідомлення, відповідь, роз'яснення, привертання уваги, звіт, подяка, вибачення, пропозиція тощо [6].

Мета статті - виявлення лінгвістичних і жанрово-стилістичних особливостей професійно орієнтованого писемного мовлення 3 погляду навчання англійського професійно орієнтованого писемного мовлення у ЗВО. Для досягнення цієї мети вивчено та проаналізовано методичну, педагогічну, лінгвістичну літературу з проблематики дослідження вітчизняних і закордонних авторів та узагальнено й систематизовано наявні наукові надбання з цієї теми.

Лінгвістичні та екстралінгвістичні риси англомовного професійно орієнтованого писемного мовлення в навчанні англійської мови.

Починаючи навчання в немовних закладах вищої освіти, студенти стикаються 3 необхідністю створювати тексти в жанрах не лише творчого писемного мовлення, із якими вони знайомились у школі, а й нові для них тексти технічного та академічного писемного мовлення. Розуміння відмінностей у цій площині, характерних ознак та жанрових особливостей англійського професійно орієнтованого писемного мовлення $є$ необхідними лінгвістичними передумовами навчання професійно орієнтованого письма англійською мовою.

Порівняльні дискурсивні дослідження дали підставу виявити характерні відмінності професійно орієнтованого технічного, академічного й творчого письма як комунікативних актів. Ч. Вілсон [17] узагальнив результати таких наукових пошуків, обравши критеріями порівняння такі категорії, як комунікативна мета, зміст, жанри, структурні та стильові особливості письма (табл. 1). 
Порівняння професійно орієнтованого технічного, академічного та творчого письма за Ч. Вілсоном

\begin{tabular}{|c|c|c|c|}
\hline & $\begin{array}{c}\text { Професійно } \\
\text { орієнтоване технічне } \\
\text { письмо } \\
\end{array}$ & Академічне письмо & Творче письмо \\
\hline $\begin{array}{l}\text { Комунікативна } \\
\text { мета }\end{array}$ & $\begin{array}{l}\text { Інформувати, } \\
\text { надати вказівки }\end{array}$ & $\begin{array}{l}\text { Переконати, } \\
\text { аргументувати }\end{array}$ & Естетична \\
\hline 3мicm & Фактичний & Фактичний & $\begin{array}{l}\text { Образний, } \\
\text { метафоричний }\end{array}$ \\
\hline Жанри & $\begin{array}{l}\text { Інструкція, } \\
\text { технічний опис, звіт, } \\
\text { меморандум тощо }\end{array}$ & $\begin{array}{l}\text { Наукове } \\
\text { повідомлення, тези, } \\
\text { статті тощо }\end{array}$ & $\begin{array}{l}\text { Оповідання, есе, } \\
\text { нарис, драма тощо }\end{array}$ \\
\hline Структура & $\begin{array}{l}>\text { Вступ } \\
>\text { Методологія } \\
>\text { Результат } \\
>\text { Висновки }\end{array}$ & $\begin{array}{l}>\text { Теза } \\
>\text { Передумови } \\
>\text { Обгрунтування }\end{array}$ & Вільна \\
\hline $\begin{array}{l}\text { Стильові } \\
\text { особливості }\end{array}$ & $\begin{array}{l}\text { • Прості, } \\
\text { стверджувальні } \\
\text { речення; } \\
\text { • короткі речення й } \\
\text { абзаци; } \\
\text { • безособовий стиль } \\
\text { викладу; } \\
\text { • формальний } \\
\text { виклад; } \\
\text { • використання } \\
\text { спеціалізованої } \\
\text { лексики }\end{array}$ & $\begin{array}{l}\text { - Ускладнені та } \\
\text { складні речення; } \\
\text { - довші речення та } \\
\text { абзаци; } \\
\text { - використання } \\
\text { особових форм; } \\
\text { - формальний } \\
\text { виклад; } \\
\text { - часткове } \\
\text { використання } \\
\text { спеціалізованої } \\
\text { лексики }\end{array}$ & $\begin{array}{l}\text { - Естетична форма } \\
\text { письма; } \\
\text { - } \text { довгі, стилістично } \\
\text { забарвлені } \\
\text { речення; } \\
\text { - } \text { особовий виклад, } \\
\text { розповідь; } \\
\text { - неформальний } \\
\text { стиль викладу; } \\
\text { - } \text { нетиповим є } \\
\text { використання } \\
\text { спеціалізованої } \\
\text { лексики } \\
\end{array}$ \\
\hline
\end{tabular}

Для професійно орієнтованого писемного мовлення властиві такі екстралінгвістичні та власне мовні риси [9]:

1) точність викладу - уживання означених слів, кількісних числівників, використання прикладів, даних і результатів досліджень;

e.g. The meeting is planned for March 18, 2004, in Conference Room C, from 8:00 a.m. -5:00 p.m.

Our quarterly sales are down $27 \%$.

2) лаконічність - уникнення багатоскладових слів, багатослівності, прийменникових фраз, використання коротких речень й абзаців;

e.g. I am in receipt of your e-mail message requesting an increase in pay. - I received your $e$ mail message requesting a pay rise.

The other alternative is to change the procedure. - The alternative is to change the procedure;

3) доступне оформлення документа - застосування шаблонів, таблиць, техніки виділення тексту, графічних засобів, заголовків, підкреслень, маркерів;

4) орієнтація на аудиторію - враховуючи потреби аудиторії й кінцевої комунікативної мети писемного мовлення. Наприклад, застосування абревіатур у письмі до колег є цілком виправданим, однак для спілкування із широкою аудиторією доцільно надавати перевагу загальновживаній лексиці;

5) граматична, лексична та змістова правильність тексту відіграє значну роль у професійно орієнтованому письмі, оскільки інформація, що викладається в письмі, зазвичай має важливе значення, відтак неправильне ії тлумачення через недоречність викладу може призвести до серйозних наслідків. 
Власне лінгвістичні відмінності в навчанні професійно орієнтованого та загальновживаного писемного мовлення також є досить значними [5]. Для навчання професійно орієнтованого писемного мовлення важливо враховувати такі характерні риси:

1) на лексичному рівні:

- використання термінології (e.g. user interface, resolution, capacity etc);

- точність значення (e.g. operating system vs operational system, electric vs. electrical etc);

- усталений порядок слів у фразах (e.g. inside out, supply and demand, profit and loss);

- використання сталих висловів (e.g. web browser, computer network, computer hardware etc);

- уживання слів з вираженим технічним забарвленням (e.g. parts - components, look into - investigate, work-operate etc);

- використання складних і складених слів, утворених за різними моделями (e.g. Noun+Adjective: user-friendly, water resistant; Noun+Noun: user interface, website, web page; Noun+Verb: troubleshooting, touch screen; Adjective+Verb: left-click, right-click);

- застосування абревіатур, скорочень (e.g. GUI-graphical user interface, LAN-local area network, HTML - hypertext markup language etc);

- нетиповим є використання емоційно-забарвлених і багатозначних слів;

2) на граматичному рівні:

- використання пасивних конструкцій (e.g. The conference was stated for March 30, 2012. The research was made to list the most popular programming languages);

- висока частотність уживання дієслова «to be» (e.g. The main part of a computer is a processor. A user guide is a technical communication document intended to give assistance to people using a particular system);

- використання інфінітива (е. g. To open the file, double-click the icon);

- застосування герундію та герундіальних конструкцій (е.g. Open the file by doubleclicking the icon);

- використання дієприкметника й дієприкметникових конструкцій (е.g. Having opened the file, copy the text).

Основні труднощі лінгвістичного характеру, із якими стикаються студенти під час написання писемних текстів на професійно-технічну тематику, визначені Л. Селінкером [16] та Ш. Пірсон [14]. Дослідники відносять до них такі:

1) уживання термінів, властивих як окремій професійній підмові, так і багатьом сферам. Такі труднощі пов'язані, передусім, із необхідністю володіння термінологією своєї професії й розумінням значень термінів та їх перекладу. Окремо треба зазначити складнощі в засвоєнні й використанні складених іменникових термінів, які значно меншою мірою властиві українській мови (наприклад, hypertext transfer protocol, graphical user interface etc.), i скорочень, загальноприйнятих у певній професійній сфері, але невідомих студентам (e.g. DDE-dynamic data exchange, FAQ - frequently asked questions, GIF - graphic interchange format);

2) використання загальновживаних слів у термінологічному значенні (e.g. architecture, mouse, bug, menu, protocol etc.), що спричиняє труднощі перекладу й розуміння.

3) модальність висловлювань - ступінь переконання автора в об'єктивності тексту, достовірності інформації, наданої в тексті. Наприклад, різний ступінь модальності містять такі два речення:

The results would seem to indicate the error in the system. - The results indicate the error in the system.

Тонка лінгвістична різниця у двох реченнях, яку не завжди можуть відзначити студенти, має, утім, суттєве значення в професійній документації, де важлива точність змісту.

4) контекстуальна парафраза - використання двох або більше слів чи висловів на позначення одного й того самого поняття, аби уникнути повторення слів. Уникнення тавтології $\epsilon$ типовим для літературної мови, однак у професійно орієнтованому письмі заміна ключових понять синонімами може призвести до неправильного тлумачення тексту. Незважаючи на це, треба звертати увагу на вживання контекстуальної заміни, особливо таких ії видів, як перехід в іншу частину мови (repeat-repetition), застосування родо-видових замінників (software-program), синонімічна заміна (display-monitor etc). 
На нашу думку, до цього списку треба додати труднощі жанрового характеру. Майбутні фахівці із системного аналізу повинні усвідомлювати, що професійно орієнтовані англомовні письмові тексти мають суттєві жанрові особливості, а тому створювати професійно орієнтовані письмові тексти потрібно, враховуючи структурні вимоги. Велике значення має правильний вибір лексичних одиниць, граматичних структур, забезпечення зв’язності тексту тощо.

Для подальшої конкретизації лінгвістичних особливостей навчання професійно орієнтованого англійського мовлення розглянемо детальніше жанрові особливості текстів ділового листа.

\section{Жанрові особливості текстів ділових листів в навчанні англійського професійно орієнтованого писемного мовлення.}

Дослідження мовленнєвих жанрів нерозривно пов'язані з іменем видатного лінгвіста М. М. Бахтіна, який вважав, що «кожне окреме висловлювання $\epsilon$, звичайно, індивідуальним, однак кожна сфера використання мови створює свої відносно стійкі типи таких висловлювань, які ми називаємо мовленнєвими жанрами» [1, с. 297]. Отже, у площині мовознавства, мовленнєвий жанр визначається як типова форма висловлювання й має такі ознаки, як цілеспрямованість, смислова завершеність, цілісність, діалогічність, безпосередній зв'язок із дійсністю [1, с. 247-255]. До типових характеристик мовленнєвого жанру відносять комунікативну ситуацію, експресію та експресивну інтонацію, обсяг, концепцію адресата та «понад адресата», протиставлення «первинних» і «вторинних» мовленнєвих жанрів.

Із позиції текстологічного підходу основою для видокремлення мовленнєвого жанру $є$ конкретний текст, що містить у собі жанрову форму, на підставі якої він співвідноситься 3 іншими текстами та змістовий критерій, а саме комунікативна мета й функція тексту [15, с. 21]. Основа визначення мети або функції тексту - відображена в тексті ситуація в сукупності 3 екстралінгвістичними умовами створення та протікання тексту. Тобто певний текст належить до певного мовленнєвого жанру, якщо його форма й зміст відповідають формі та змісту текстів цього жанру [15].

Ділові листи в професійній діяльності аналітиків систем слугують засобом зв'язку з колегами, організації спільної праці та повідомлень важливої інформації. Навчання написання ділових листів розглянуто в методиці викладання англійської мови як потужний засіб професіоналізації [3, с. 15]. Дійсно, цей жанр - найбільш затребувана форма англомовної письмової комунікації в професійній сфері, оскільки залучає комунікантів у ділове спілкування та партнерство. Пандемія коронавірусу, що охопила світ у 2020 р., посприяла поширенню віддаленого письмового спілкування, що додає вмінню писати ділові листи особливої актуальності. Зарубіжні дослідники до стандартизованих ділових листів відносять лист-запит, пропозицію, замовлення, підтвердження, відмову, супровідний лист, лист-скаргу тощо.

До загальностилістичних рис ділового листа як різновиду офіційно-ділового стилю відносять стандартизованість та уніфікованість планів форми й змісту, точність позначення понять, термінологічний характер лексики, фактичність викладу реальних подій, безособовість, практичну цілеспрямованість, часову обмеженість строку дії тощо [8, с. 199].

Усі ділові листи виконують комунікативну функцію активізації (впливу) в іiі різноманітних формах (спонукальній, регулятивній, контактовстановлювальній) [6, с. 49]. Діловий лист відзначається єдиною темою, особливим графічним оформленням, композиційною будовою, часовою та просторовою точністю, документальністю й використанням засобів мовного етикету для забезпечення адекватності сприйняття змісту адресатом (С. Ю. Федюрко [7]).

Стандартизована структурно-композиційна будова ділових листів передбачає поділ тексту на логічні частини, такі як:
1. Реквізити сторін.
2. Дата.
3. Привітання.
4. Основна частина.
5. Підпис.

Ядром ділового листа, у якому передається денотативна інформація й реалізується комунікативна функція, є основна частина. Частини привітання та підпису листа виконують 
етикетну функцію і є, по суті, мовними кліше. Реквізити сторін та дата можуть викликати певні труднощі соціокультурного характеру у зв'язку з відмінностями форм представлення цих параметрів у різних мовах.

Серед лінгвістичних особливостей ділових листів потрібно зазначити такі:

1) лексичне розшарування, поділ уживаної лексики на три окремі групи: загальновживаних слів (write, receive, inform etc), спеціальної ділової лексики (enquiry, insurance, supplies etc), і власне професійних термінів (personal computer, maintenance, software etc);

2) забезпечення зв'язності тексту за допомогою слів-зв'язок (and, but, also, besides etc);

3) використання стереотипних кліше, які Т. А. Крисанова класифікує за тематичною ознакою на кліше замовлення, пропозиції, претензії, скарги, запиту, повідомлення, вибачення, прохання [11]. (e.g. Please find enclosed..., with reference to..., we regret to inform, we offer our apologies... we should be obliged etc.);

4) використання засобів мовної економії, абревіатур та скорочень (е.g. a.a.r. (against all risks), advt. (advertisement), chq (cheque) etc.);

5) переважання простих речень з ускладненою структурою через інфінітивні конструкції, герундій, дієприкметникові звороти, наприклад:

We expect the goods to be loaded at once.

When unpacking the goods we experienced damages.

You having been most successful in selling other goods, we offer you...

5) переважання дійсного та умовного способів дієслів, наприклад:

e.g. We would be grateful if you could confirm...

Thank you in advance.

Порівняльний аналіз англомовних й українських ділових листів виявив такі лінгвістичні відмінності, як відсутність герундію в українській мові (передається розширеним реченням, віддієслівними іменниками), складнощі під час передачі дієприкметникових та інфінітивних зворотів, які трансформуються в підрядні речення й нетиповість використання імперативної форми дієслова в англійських листах, на противагу українським [11].

Висновки. Навчання професійно орієнтованого писемного мовлення набуває особливої актуальності в умовах сьогодення, і для успішного навчання цього виду мовленнєвої діяльності на заняттях англійської мови у ЗВО важливо враховувати низку лінгвістичних передумов. Узагальнивши дослідження з проблематики, доцільно виокремити певні екстралінгвістичні та власне мовні риси професійно орієнтованого писемного мовлення, такі як точність викладу, лаконічність, доступне оформлення документа, орієнтованість на аудиторію, граматична, лексична та змістова правильність тексту. Для навчання професійно орієнтованого писемного мовлення важливим $є$ врахування таких характерних рис, як використання термінології, точність значення, усталений порядок слів у фразах, використання сталих виразів, використання слів 3 вираженим технічним забарвленням, використання складних і складених слів, утворених за різними моделями, використання абревіатур, скорочень, пасивних конструкцій, інфінітива, герундія та герундіальних конструкцій, дієприкметника та дієприкметникових конструкцій. Зазначені лінгвістичні передумови $є$ основою для подальшої розробки системи вправ для навчання професійно орієнтованого писемного мовлення.

\section{References}

1. Bakhtin, Mykhail. 1979. Estetika slovesnoho tvorchestva. Moscow: Iskustvo.

2. Bazvanova, Tatiana. 2005. "Obuchenye inostrannykh studentov i spetsyalistov nefilolohicheskoho profilia delovomu pismu s ispolzovaniem distantsionnykh tekhnolohii”. PhD diss., Moscow.

3. Bezus, Svetlana. 2004. "Obuchenie elementam delovoho pisma uchashchikhsia starshykh klassov srednei shkoly: na materiale angliiskogo yazyka". PhD diss., Piatigorsk.

4. Bykonia, O. 2013. "Lingvistychni osoblyvosti dilivoho anglomovnogo elektronnogo pysemnogo movlennia". Modern problems of education and science: conference, $26^{\text {th }}-27^{\text {th }}$ January, Budapest URL: http://scaspee.com/6/ post/2013/06/reports-of-conference-modern-problems-of-education-and-science-budapest-2013-january-26th27th.html

5. Caissie, Kathleen. 1978. A Handbook for Teaching Technical English. AYMAT Individual Thesis: SMAT IPP Collection.

6. Dautova, Huzial. 2004. “Kognitivnaia model tipologicheskogo analiza teksta delovoho pisma”. PhD diss., Ufa. 
7. Fediurko, Sergei. 2002. "Stilisticheskiie osobennosti russkogo delovogo pisma kak zhanrovoi raznovidnosti ofotsialno-delovogo stilia". PhD diss., Voronezh.

8. Fen, Hunmei. 2006. "Zhanr delovogo pisma i ego subzhanry". PhD diss., Moscow.

9. Gerson, Steven. 2001. Writing that Works: A Teacher`s Guide to Technical Writing. Washburn: Kansas Competence-Based Curriculum Center, Washburn University.

10. Kameneva, Tetiana. 2009. "Metodyka navchannia maibutnikh menedzheriv dilovoho pysemnoho spilkuvannia anhliiskoiu movoyu z vykorystanniam elektronnoho pidruchnyka". PhD diss., Kyiv.

11. Krysanova, Tetiana. 2009. "Leksyko-hramatychni osoblyvosti anhliiskoho ta ukrainskoho dilovoho lysta komparatyvnyi aspekt”. Naukovyi Visnyk Volynskoho natsionalnoho universytetu imeni Lesi Ukrainky 17: 31-35.

12. Making the Most of Our Potential: Consolidating the European Higher Education Area. Bucharest Communiqué: EHEA Ministerial Conference (Bucharest, 26-27 April 2012). European Higher Education Area, Bologna Process. Bucharest.

13. Mokwa-Tarnowska, Iwona. "Teaching technical writing in English in a traditional classroom setting and in online courses". URL: http://spnjo.polsl.pl/konferencja/materialy/ referaty/mokwa-tarnowska.pdf.

14. Pearson, Sheryl. 1983. "Teaching technical writing to the foreign-born professional in industry". TESOL Quarterly 17(3): 383-399.

15. Rekhtin, Lev. 2005. "Rechevoi zhanr instruktsii: polevaia organizatsiya". PhD diss., Gorno-Altaisk.

16. Selinker, Larry. 1979. "On the use of informants in discourse analysis and "language for specialized purposes". International Review of Applied Linguistics in Language Teaching 17(3): 189-215.

17. Wilson, Chad. 2012. "A Novel approach to teaching technical writing". American Society for Engineering Education.

Баклаженко Юлия. Лингвистические предпосылки обучения английской профессионально ориентированной письменной речи в вузах. Обучение профессионально ориентированной письменной речи как средства удаленной коммуникации и профессионализации играет сегодня значительную роль в связи с высокими требованиями к подготовке специалистов из разных областей знаний в современных условиях. В статье рассматриваются лингвистические предпосылки обучения английской профессионально ориентированной письменной речи в учреждениях высшего образования. В частности, определяются характерные отличия профессионально ориентированного технического, академического и творческого письма как коммуникативных актов, определяются экстралингвистические и собственно языковые черты профессионально ориентированной письменной речи, такие как точность изложения, лаконичность, доступное оформление документа, ориентированность на аудиторию, грамматическая, лексическая и содержательная правильность текста. Выявлено, что для обучения профессионально ориентированной письменной речи важно учитывать такие характерных черты, как использование терминологии, точность значения, устоявшийся порядок слов во фразах, использование устойчивых выражений, использование слов с выраженной технической окраской, использование сложных и составных слов, образованных по различным моделям, использование аббревиатур, сокращений, пассивных конструкций, инфинитива, герундия и герундиальных конструкций, причастия и причастных конструкций. Указываются также трудности лингвистического характера, с которыми сталкиваются студенты при написании письменных текстов профессионально-технической тематики. Анализируются стилистические черты жанра делового письма, его коммуникативная функция, структурно-композиционное строение, лингвистические особенности и различия с точки зрения обучения английской профессионально ориентированной письменной речи в учреждениях высшего образования.

Ключевые слова: обучение английскому языку, английская профессионально ориентированная письменная речь, английский для профессиональных целей, деловое письмо.

Baklazhenko Yuliia. Linguistic Preconditions for Teaching Professionally Oriented English Writing in Higher Educational Institutions. The teaching of professionally oriented written speech as a means of remote communication and professionalization plays a significant role today due to the high requirements for the training of specialists in various fields of knowledge and current trends and conditions of professional life. The article is devoted to the linguistic preconditions of teaching professionally oriented English writing in higher education institutions. In particular, the characteristic differences of professionally oriented technical, academic and creative writing as communicative acts are outlined, extralinguistic and linguistic features of professionally oriented written speech are determined, such as accuracy of presentation, conciseness, accessible document design, audience orientation, grammatical, lexical and textual correctness. It is revealed that for teaching professionally oriented English writing it is important to take into account such characteristic features as use of terminology, accuracy of meaning, established word order in phrases, use of constant expressions, use of words with technical colour, use of abbreviations, acronyms, passive constructions, infinitive, gerund and gerund constructions, adjective and adjective constructions. There are also difficulties of a linguistic nature, which students face when writing texts on professional and technical topics. The author analyzes the general stylistic features of the business letter genre, its communicative function, structural and compositional structure, linguistic features and differences in terms of teaching professionally oriented English writing in higher education.

Key words: English language teaching, professionally oriented English writing, English for professional purposes, business letter. 